\title{
Faktor-Faktor yang Mempengaruhi Minat Siswa Melanjutkan Pendidikan Tinggi Ke Universitas Terbuka (Studi Kasus SLTA Negeri dan Swasta Sederajat di Provinsi Jambi)
}

\author{
Mahyudin ${ }^{1}$
}

\begin{abstract}
Abstrak: Penelitian ini bertujuan untuk mengetahui apakah faktor-faktor yang mempengaruhi minat siswa melanjutkan pendidikan tinggi ke Universitas Terbuka (Studi kasus SLTA negeri dan swasta sederjat di Provinsi Jambi). Populasi penelitian ini adalah siswa SMA Negeri dan Swasta di Provinsi Jambi melanjutkan pendidikan tinggi ke Universitas Terbuka dengan menggunakan teknik cluster sampling. Dimana teknik tersebut tidak tersedia kerangka sampel, masing-masing unit dari populasi disusun kedalam grup/cluster, dalam hal ini adalah Kabupaten dan Kota di Provinsi Jambi sebagai klusternya.Kemudian setiap Kabupaten dan Kota dipilih 3 sekolah secara random sederhana dan diambil 10 sampel dari masing-masing sekolah. Jumlah sampelnya adalah 330 siswa atau siswi SMA/K sederajat di kelas XII. Metode analisis data yang digunakan untuk mengidentifikasi karakteristik responden yang diambil adalah dengan menggunakan analisis deskriptif. Analisis Data yang digunakan untuk mengetahui faktor-faktor yang mempengaruhi minat siswa melanjutkan pendidikan tinggi ke Universitas Terbuka (Studi Kasus SMA sederajat Negeri dan Swasta di Provinsi Jambi) dengan menggunakan software SPSS 18. Adapun karakteristik responden yang dianalisis antara lain jenis kelamin, status siswa, pendidikan orang tua, pekerjaan orang tua, penghasilan orang tua, tempat tinggal siswa, pelajaran yang disukai, tempat saudara berkuliah, faktor pendorong, dan nilai rapor. Analisis regresi logistik menggunakan peubah penjelasnya yang dapat berupa peubah kategorik ataupun peubah numerik yang bertujuan untuk menduga besarnya peluang kejadian tertentu dari kategori peubah respon (Firdaus, Rahmini, Farid, 2011). Hosmer, David W. dan Lemeshow, Stanley (2000) menunjukkan bahwa vektor $x^{\prime}=(x 1, x 2, \ldots, x p)$ menotasikan sebanyak $\mathrm{p}$ variabel bebas yang dilibatkan. $\mathrm{P}(\mathrm{Y}=1 \mathrm{x})=\pi(\mathrm{x})$ adalah peluang bersyarat bahwa variabel tidak bebas menyatakan kejadian $(\mathrm{y}=1)$.
\end{abstract}

Kata kunci: Minat Tamatan SLTA Melanjutkan ke Universitas Terbuka.

Abstract : This study aims to determine whether the factors that influence high school students to the Open University (public and private high school case studies are as well as Jambi Province). The population of this study is the technique used in research to help public and private high school students in Jambi Province, higher education to the Open University in this study using cluster sampling technique. With a method where no sample is available, each unit of the group is in a group / cluster, in this case the regencies and cities in Jambi Province as clusters. Then each district and city is selected in 3 simple random schools and given 10 samples from each -something of each school. The number of samples is 330. The sample unit is high school / high school students or equivalent in class XII. Data analysis method used for respondents is descriptive analysis. The data used to determine the factors that influence students' interest in Higher Education to Open University (Case Study of State and Private High Schools in Jambi Province) using SPSS 18 software. The analysis was conducted to determine the number of respondents in this study. Respondents used were parents, parents of students, parents, parents, parents, residence of students, teachers, college people, driving factors, and report card grades. Logistic regression analysis uses explanatory variables that can be categorical variables or numerical variables that aim to identify the probability of occurrence of variable response categories (Firdaus, Rahmini, Farid, 2011). Hosmer, David W. and Lemeshow, Stanley (2000) show that the vector $x$ $'=(x 1, x 2, \ldots, x p)$ denotes as many variables as possible. $P(Y=1 x)=\pi(x)$ is a chance that the non-independent variable states the event $(y=1)$.

Keywords: High School Graduates' Interests Continuing to Open University.

\section{PENDAHULUAN}

Pendidikan adalah hak dasar yang harus diperoleh oleh manusia, di samping pangan dan papan. Hal ini telah dimuat dalam Undang-Undang Dasar 1945 Pasal 28c ayat (1) yang menyatakan bahwa "Setiap orang berhak mengembangkan diri melaluipemenuhan kebutuhan dasarnya, berhak mendapat pendidikan dan memperolehmanfaat dari ilmu pengetahuan dan teknologi, seni dan budaya, demi meningkatkankualitas hidupnya dan demi kesejahteraan umat manusia" dan Pasal 31 menyatakan "Pemerintah wajib memajukan

\footnotetext{
${ }^{1}$ Dosen Universitas Terbuka
} 
pendidikan dengan mengusahakandan menyelenggarakan satu sistem pendidikan nasional, yang meningkatkan keimanan dan ketakwaan serta akhlak mulia dalam rangka mencerdaskan kehidupan bangsa, yang diatur dengan undang-undang, memprioritaskan anggaran pendidikan, serta memajukanilmu pengetahuan dan teknologi dengan menjunjung tinggi nilai- nilai agama dan persatuan bangsa untuk kemajuan peradaban serta kesejahteraan umat manusia". Visi dari pendiri bangsa tersebut menjadikan pendidikan adalah hak dari setiap warga negara.

Salah satu jenjang pendidikan formal di Indonesia adalah pendidikan menengah (SMA, SMK, dan Madrasah Aliyah). Pendidikan menengah adalah pendidikan yang lamanya tiga tahun yang bertujuan untuk melanjutkan dan meluaskan pendidikan dasar serta mempersiapkan peserta didik menjadi anggota masyarakat yang memiliki kemampuan mengadakan hubungan timbal balik dengan lingkungan sosial, budaya, dan alam sekitar, serta dapat mengembangkan kemampuan lebih lanjut dalam memasuki dunia kerja maupun pendidikan selanjutnya yaitu pendidikan tinggi (Indriyanti, Siswandari, dan Ivada, 2013). Di Provinsi Jambi terdapat 192 SMA Negeri dan 190 SLTA sederajat Swasta dengan jumlah lulusan sebanyak 74.447 orang pada tahun ajaran 2016/2017 (Kementerian Pendidikan dan Kebudayaan, 2017). Dari seluruh siswa yang menamatkan pendidikan di SLTA sederajat negeri dan swasta di Provinsi Jambi, tidak semuanya melanjutkan ke pendidikan tinggi. Hal ini dikarenakan faktor ekonomi, budaya, dan seleksi masuk ke perguruan tinggi negeri. Padahal daya tampung di universitas-universitas yang ada di Provinsi Jambi mencapai 12.000 kursi.

Universitas Terbuka (UT) adalah Perguruan Tinggi Negeri ke-45 di Indonesia yang diresmikan pada tanggal 4 September 1984 berdasarkan Keputusan Presiden RI Nomor 41 Tahun 1984. UT memiliki 4 fakultas, yaitu Fakultas Ekonomi (FEKON), Fakultas Hukum dan Ilmu Sosial dan Ilmu Politik (FHISIP), Fakultas Matematika dan Ilmu Pengetahuan Alam (FMIPA),dan Fakultas Keguruan dan Ilmu Pendidikan (FKIP)untuk jenjang Diploma dan Sarjana. Universitas Terbuka adalah pelopor pendidikan terbuka dan jarak jauh di Indonesia yang salah satu unit pelaksana teknisnya terdapat di Kota Jambi (UPBJJ-UT Jambi). UPBJJ-UT Jambi memiliki wilayah kerja meliputi 10 kabupaten dan kota yaitu Tanjab Timur, Tanjab Barat, Muaro Jambi, Batanghari, Tebo, Muaro Bungo, Sarolangun, Merangin, Kerinci, dan Kota Jambi. Pada akhir tahun 2016, UPBJJ-UT Jambi memiliki mahasiswa aktif sebanyak 3.484 mahasiswa, dimana $40 \%$ diantaranya adalah para guru SD dan guru PAUD yang sedang mengabdi di sekolah-sekolah di seluruh Provinsi Jambi yang merupakan wilayah kerja UPBJJ-UT Jambi. Sedangkan yang 60\% adalah mahasiswa yang menempuh di 24 program studi pada 4 fakultas FEKON, FHISIP, FMIPA, FKIP, dan Pasca Sarjana (Universitas Terbuka Jambi, 2016).

Berbagai permasalahan pendidikan Indonesia karena banyaknya hambatan menuntut Universitas Terbuka meningkatkan kualitasnya. Rata-rata pendidikan masyarakat Indonesia yang masih setingkat pendidikan dasar menengah dan relatif tertinggal dibandingkan negara maju, bahkan negara tetangga. Hal ini mengharuskan Universitas Terbuka semakin inovatif dalam menyelenggarakan kegiatan perkuliahan, baik dari aspek biaya maupun pelaksanaan perkuliahan.

Mayoritas siswa-siswa di SLTA sederajat Negeri/Swasta Provinsi Jambi menginginkan untuk melanjutkan pendidikan di universitas, baik negeri maupun swasta. UT sebagai salah satu universitas negeri yang memberikan kemudahan bagi masyarakat yang ingin melanjutkan ke jenjang pendidikan yang lebih tinggi, adalah salah satu alternatif untuk memperoleh ilmu dan gelar. Hambatan ekonomi, geografis, dan demografis diminimalisir. Penelitian ini dilakukan untuk mencapai tujuan penelitian diantaranya: 1) Mengetahui karakteristik minat siswa SLTA sederajat Negeri/Swasta di Provinsi Jambi untuk melanjutkan pendidikan tinggi ke Universitas Terbuka, 2) Menganalisis faktor-faktor yang mempengaruhi minat siswa SLTA sederajat Negeri/Swasta di Provinsi Jambi untuk melanjutkan pendidikan tinggi ke Universitas Terbuka dengan menggunakan model regresi logistik.

Crow dan Crow (1998:352), mendefinisikan tentang minat, yaitu "minat atau interest bisa berhubungan dengan daya gerak yangmendorong kita untuk cenderung atau merasa tertarik kepada orang, benda, ataupun bisa berupa pengalaman yang efektif yang dirangsang oleh kegiatan itu sendiri". Sedangkan Muhibin (2009) menjelaskan bahwa minat adalah kecenderungan dan kegairahan yang tinggi atau keinginan yang besar terhadap sesuatu. Dari dua pengertian tersebut didapatkan kesimpulan bahwa minat adalah kecenderungan diri kepada sesuatu karena ada kepentingan dengan sesuatu itu. Dalam hal ini adalah minat siswa SLTA sederajat melanjutkan ke Universitas Terbuka. 
Monks, Knoers, dan Haditono (2008:189) menjelaskan bahwa ada aktor yang mempengaruhi minat seseorang yaitu faktor dari dalam (intrinsik), yaitu sifat pembawaan, dan faktor dari luar (ekstrinsik), diantaranya keluarga, sekolah dan masyarakat sekitar. Minat yang terjadi dalam individu dipengaruhi dua faktor yang menentukan, yaitu faktor keinginan dari dalam danfaktor keinginan dari luar. Minat dari dalam terdiri dari tertarik ataurasa senang pada kegiatan, perhatian terhadap suatu kegiatan danadanya aktivitas atau tindakan akibat rasa senang maupunperhatian". Sedangkan Slameto (2010) menjelaskan bahwa minatdipengaruhi oleh faktor pekerjaan, sosial ekonomi, bakat, umur, jeniskelamin, pengalaman, kepribadian, dan lingkungan. Minat siswa SMA di Provinsi Jambi untukmelanjutkan pendidikan ke Universitas Terbuka bisa dipengaruhi oleh faktor intrinsik dan ekstrinsik. Untuk mengetahui faktor tersebut, maka perlu dilakukan penelitian ini.

Hasil penelitian terdahulu yang terkait minat siswa melanjutkan pendidikan tinggi ke universitas dilakukan oleh Andanawari (2010). Hasil penelitian menunjukkan bahwa faktor-faktor yang berpengaruh terhadap minat siswa melanjutkan ke perguruan tinggi adalah jenis kelamin, rata-rata penghasilan orang tua, serta faktor pendorong. Sementara itu, siswa SMU lebih berminat melanjutkan pendidikan ke perguruan tinggi dibandingkan siswa yang berasal dari sekolah SMK dan Madrasyah Aliyah. Namun perbedaan minat tersebut lebih didasarkan pada pendapatan orang tua yang memang berbeda pada ketiga strata sekolah tersebut.

Arnawan (2016) mengemukakan bahwa faktor internal penyebab kurangnya minat remaja desa terhadap pendidikan di perguruan tinggi di Desa Balirejo adalah kurangnya motivasi atau keinginan untuk kuliah dan keinginan untuk mandiri dengan mencari kerja. Sedangkanfaktor eksternal penyebab kurangnya minat remaja desa pendidikan di perguruan tinggi di desa Balirejo adalah faktor keterbatasan ekonomi atau biaya pendidikan yang mahal dan faktor lingkungan dan budaya.

Hasil penelitian yang lain dari Indriyanti, Siswandari, dan Ivada (2013) menunjukkan bahwa terdapattujuh faktor yang memengaruhi minat siswa SMK melanjutkan pendidikan ke perguruan tinggi. Ketujuh faktor tersebut adalah a) faktor potensi diri yang mewakili variabel bakat dengan indikator pengembangan bakat dan bakat dalam diri, sikap dengan indikator keaktifan, motivasi dengan indikator dorongan internal, cita-cita dengan indikator kemapanan, dan prestasi dengan indikator persaingan akademik. b) Faktor motivasi yang mewakili variabel kepribadian dengan indikator keyakinan dan pengembangan diri, prestasi dengan indikator beasiswa, teman-teman dengan indikator bahan pembicaraan, motivasi dengan indikator dukungan orang tua, dan sikap dengan indikator usaha. c) Faktor ekspektasi masa depan yang mewakili variabel prestasi dengan indikator tingkat prestasi dan kepribadian denganindikator masa depan. d) Faktor peluang yang mewakili variabel cita-cita dengan indikator jenis pekerjaan, pengalaman dengan indikator kesuksesan, dan motivasi dengan indikator kemudahan memperoleh pekerjaan. e) Faktor lingkungan sosial yang mewakili variabel lingkungan masyarakat dengan indikator persepsi masyarakat, teman-teman dengan indikator pengaruh teman dan sekolah dengan indikator guru. f) Faktor situasi dan kondisi yang mewakili variabel keluarga dengan indikator pendapatan orang tua dan pendidikan orang tua dan pengalaman dengan indikator pengangguran. g) Faktor institusional yang mewakili variabel sekolah dengan indikator kurikulum. Faktor yang paling besar memengaruhi minat siswa melanjutkan pendidikan ke perguruan tinggi adalah faktor potensi. Faktor ini terdiri dari variabel bakat dengan indikator pengembangan bakat dan bakat dalam diri, sikap dengan indikator keaktifan, motivasi dengan indikator dorongan internal, cita-cita dengan indikator kemapanan, dan prestasi dengan indikator persaingan akademik.

\section{METODE PENELITIAN}

Desain penelitian yang digunakan dalam penelitian ini adalah penelitian deskriptif. Populasi dalam penelitian ini adalah siswa SMA Negeri dan Swasta di Provinsi Jambi dengan menggunakan teknik cluster sampling. Dimana teknik tersebut tidak tersedia kerangka sampel, masing-masing unit dari populasi disusun kedalam grup/cluster, dalam hal ini adalah Kabupaten dan Kota di Provinsi Jambi sebagai klusternya.Kemudian setiap Kabupaten dan Kota dipilih 3 sekolah secara random sederhana dan diambil 10 sampel dari masing-masing sekolah. Jumlah sampelnya adalah 330 siswa atau siswi SMA/K sederajat di kelas XII. 
Metode analisis data yang digunakan untuk mengidentifikasi karakteristik responden yang diambil adalah dengan menggunakan analisis deskriptif dengan menggunakan software SPSS 18 dan analisis regresi logistik. Adapun karakteristik responden yang dianalisis antara lain jenis kelamin, status siswa, pendidikan orang tua, pekerjaan orang tua, penghasilan orang tua, tempat tinggal siswa, pelajaran yang disukai, tempat saudara berkuliah, faktor pendorong, dan nilai rapor.

\section{HASIL DAN PEMBAHASAN}

\section{Karakteristik Minat Siswa SLTA sederajat Negeri/Swasta di Provinsi Jambi untuk Melanjutkan Pendidikan Tinggi ke Universitas Terbuka.}

Karakteristik siswa SLTA sederajat Negeri/Swasta di Provinsi Jambi menunjukkan hasil yang beraneka ragam mengenai minat mereka untuk melanjutkan pendidikan tinggi ke Universitas Terbuka. Karakteristik yang dilihat diantaranya adalah jenis kelamin, status anak, pendidikan ayah, pendidikan ibu, pekerjaan ayah, pekerjaan ibu, rata-rata pendapatan orang tua, pelajaran yang disukai, perguruan tinggi saudara berkuliah, faktor pendorong memilih perguruan tinggi, nilai raport, dan tempat tinggal siswa.

\section{Jenis Kelamin}

Gambar 1`menunjukkan bahwa siswa laki-laki dan perempuan memiliki kecenderungan tidak berminat untuk masuk ke Universitas Terbuka. Mereka menganggap bahwa Universitas Terbuka dapat menjadi pilihan PTN lain apabila mereka tidak diterima di PTN atau PTS favorit dan apabila mereka memiliki kendala biaya. Sebesar 61 persen siswa SMA Negeri dan Swasta di Provinsi Jambi tidak berminat untuk melanjutkan ke pendidikan tinggi ke universitas terbuka. Hal ini bisa dilihat pada gambar berikut:

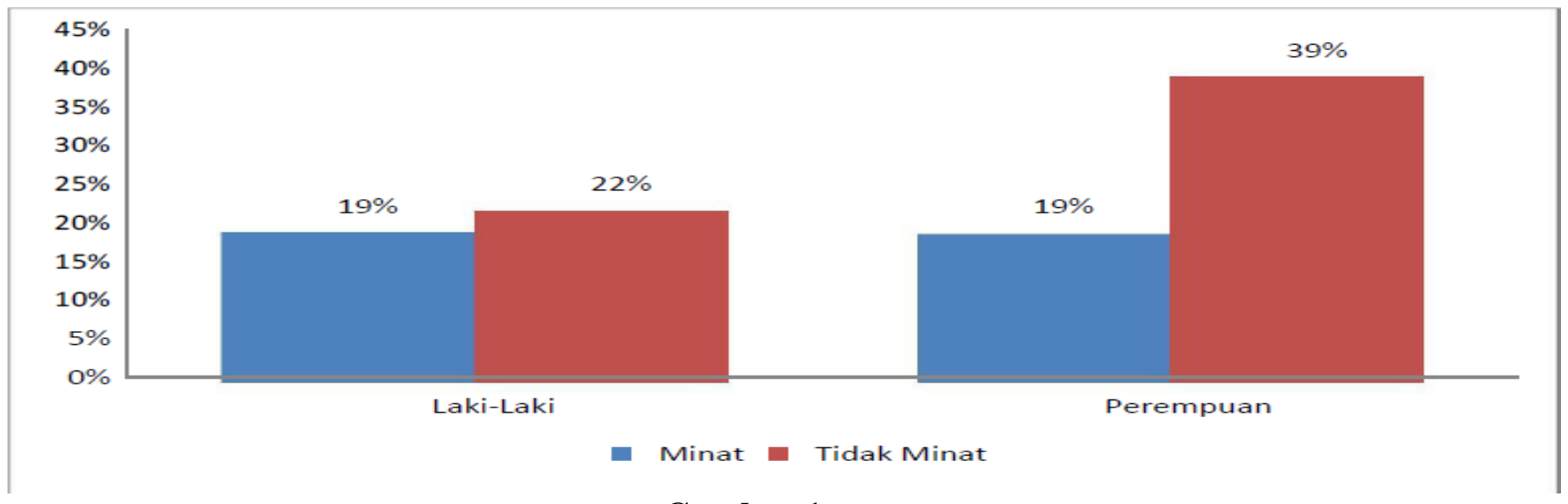

Gambar 1.

Karakteristik Minat Siswa SLTA sederajat Negeri/Swasta di Provinsi Jambi untuk Melanjutkan Pendidikan Tinggi ke Universitas Terbuka berdasarkan Jenis Kelamin

\section{Status Anak}

Gambar 2 menunjukkan bahwa baik anak pertama maupun bukan anak pertama memiliki kecenderungan tidak berminat untuk melanjutkan pendidikan tinggi di Universitas Terbuka. Kecenderungan minat mereka untuk masuk ke Universitas Terbuka cukup rendah, yaitu hanya 39 persen.

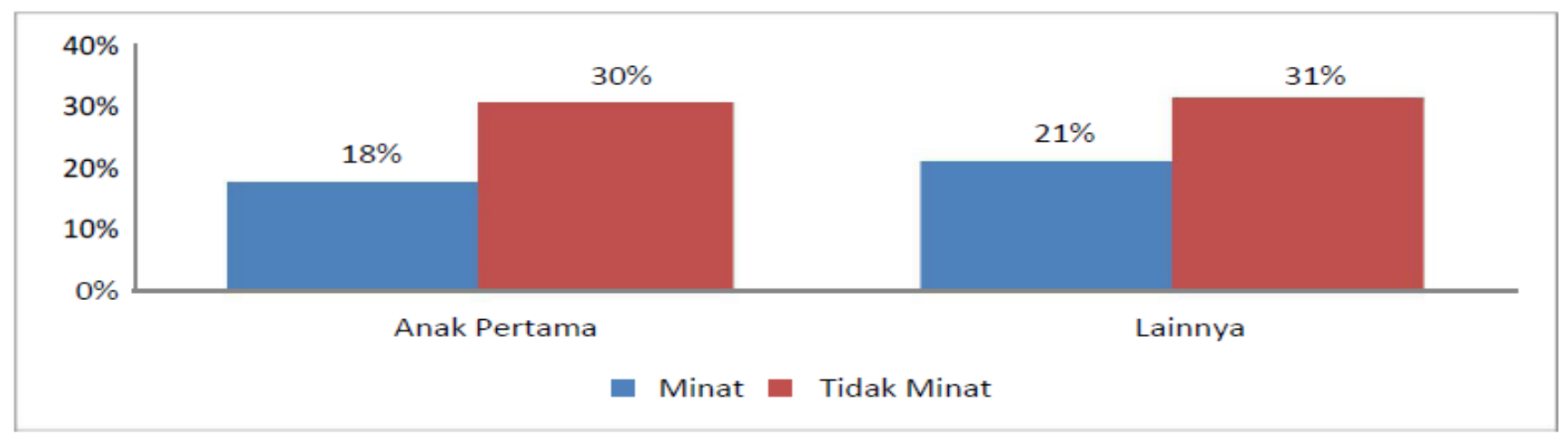




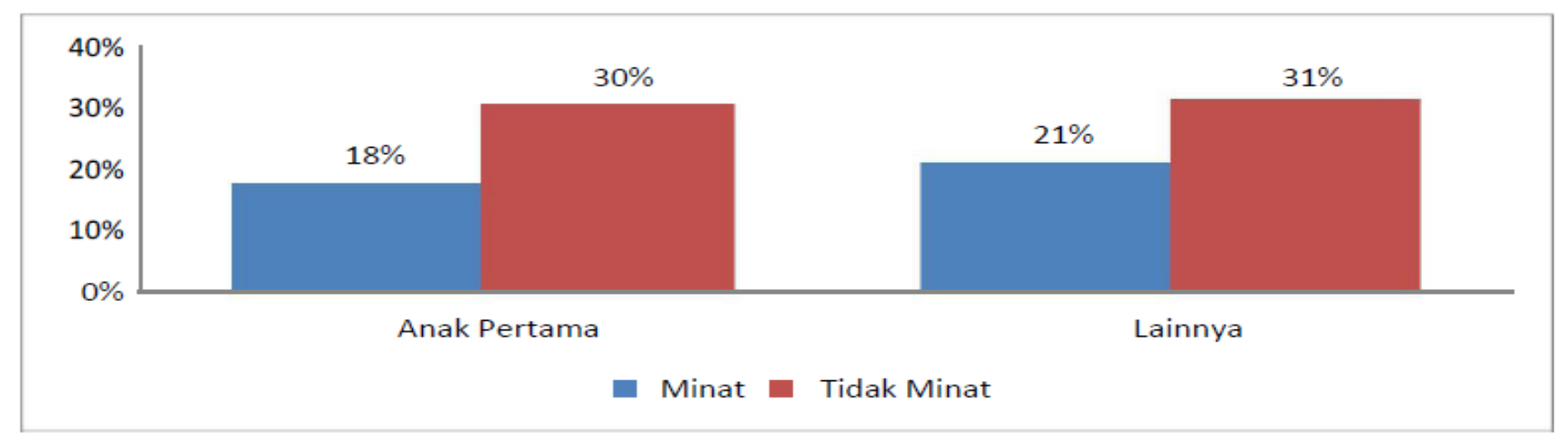

\section{Gambar 2.}

Karakteristik Minat Siswa SLTA sederajat Negeri/Swasta di Provinsi Jambi untuk Melanjutkan Pendidikan Tinggi ke Universitas Terbuka berdasarkan Status Anak

\section{Pendidikan Ayah}

Karakteristik pendidikan ayah yang terlihat di Gambar 3 pun menunjukkan bahwa minat siswa untuk berkuliah yang rendah di Universitas Terbuka. Hanya sebesar 39 persen siswa SMA Negeri dan Swasta di Provinsi Jambi dari karakteristik pendidikan ayah yang berminat melanjutkan pendidikan tinggi ke Universitas Terbuka.

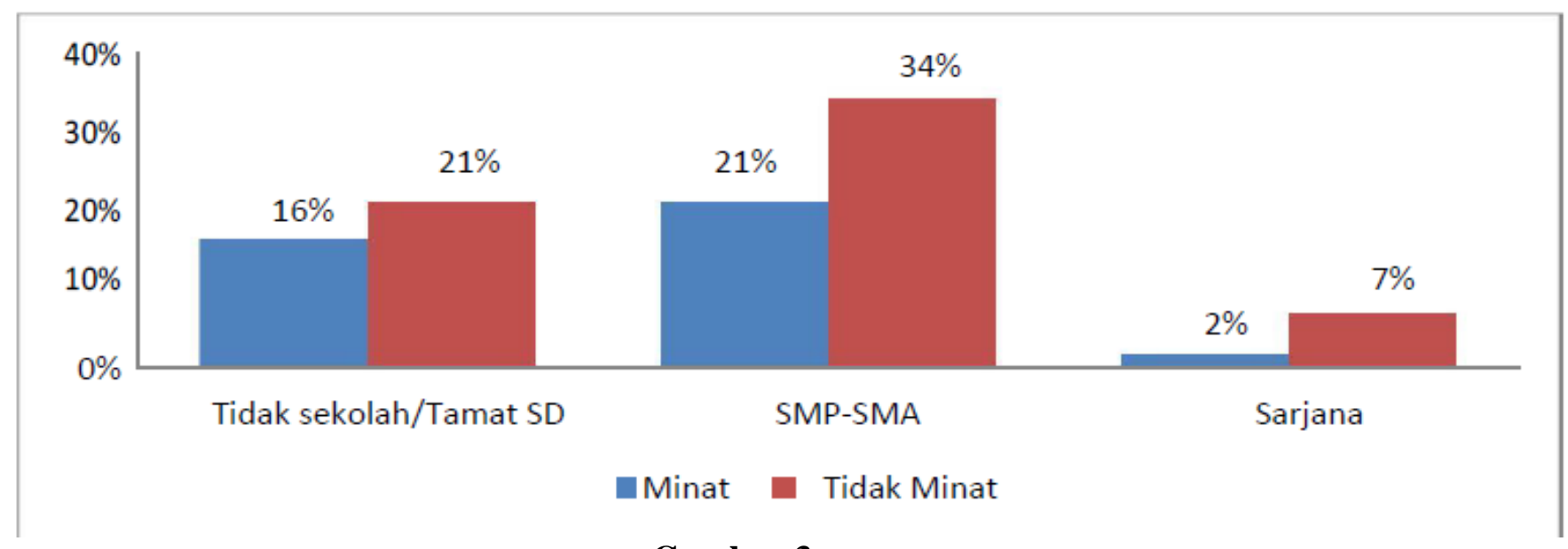

Gambar 3.

Karakteristik Minat Siswa SLTA sederajat Negeri/Swasta di Provinsi Jambi untuk Melanjutkan Pendidikan Tinggi ke Universitas Terbuka berdasarkan Pendidikan Ayah

\section{Pendidikan Ibu}

Gambar 4 menunjukkan hal yang sama seperti gambar sebelumnya, di mana minat siswa untuk berkuliah yang rendah di Universitas Terbuka. Hanya sebesar 39 persen siswa SMA Negeri dan Swasta di Provinsi Jambi dari karakteristik pendidikan ibu yang berminat melanjutkan pendidikan tinggi ke Universitas Terbuka.

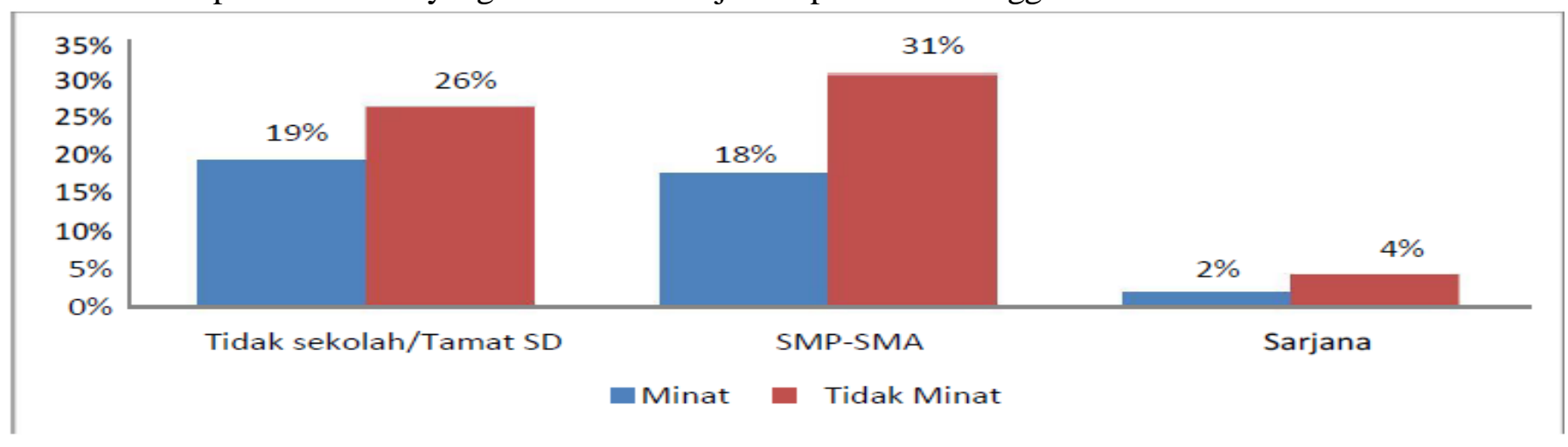




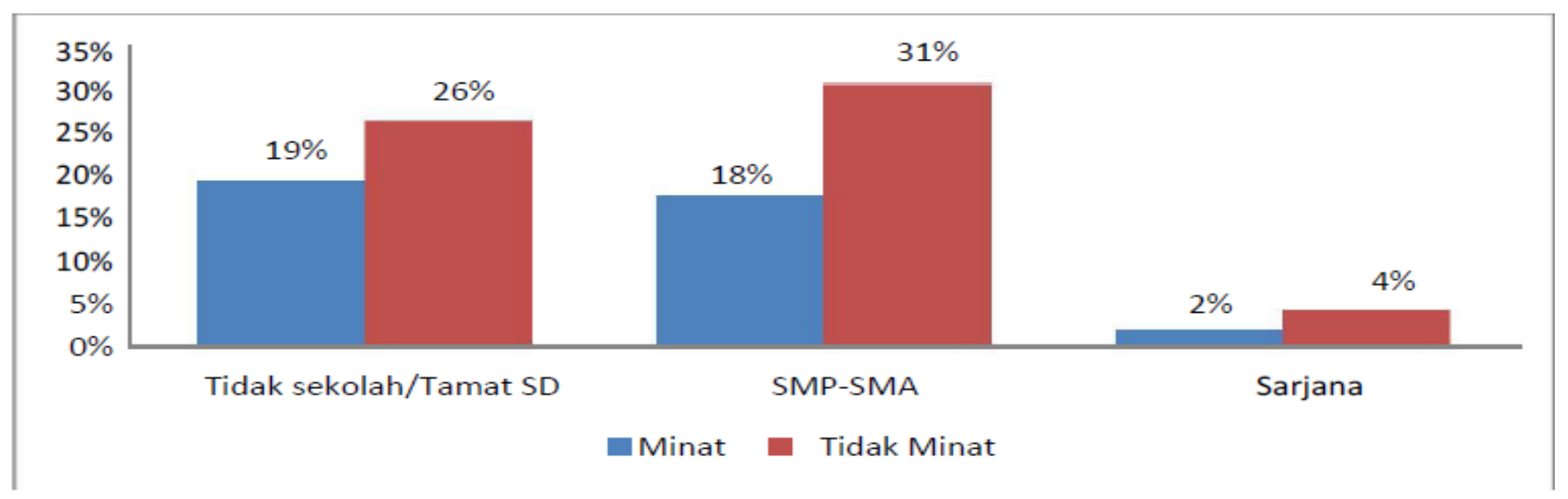

Gambar 4.

Karakteristik Minat Siswa SLTA sederajat Negeri/Swasta di Provinsi Jambi untuk Melanjutkan

Pendidikan Tinggi ke Universitas Terbuka berdasarkan Pendidikan Ibu

\section{Pekerjaan Ayah}

Gambar 5 menunjukkan bahwa hampir tidak ada ayah yang bekerja sebagai PNS ingin anaknya melanjutkan pendidikan tinggi ke Universitas Terbuka. Masih seperti gambar sebelumnya di mana mayoritas siswa SMA Negeri dan Swasta di Provinsi Jambi dari karakteristik pekerjaan ayah yang tidak berminat melanjutkan pendidikan tinggi ke Universitas Terbuka

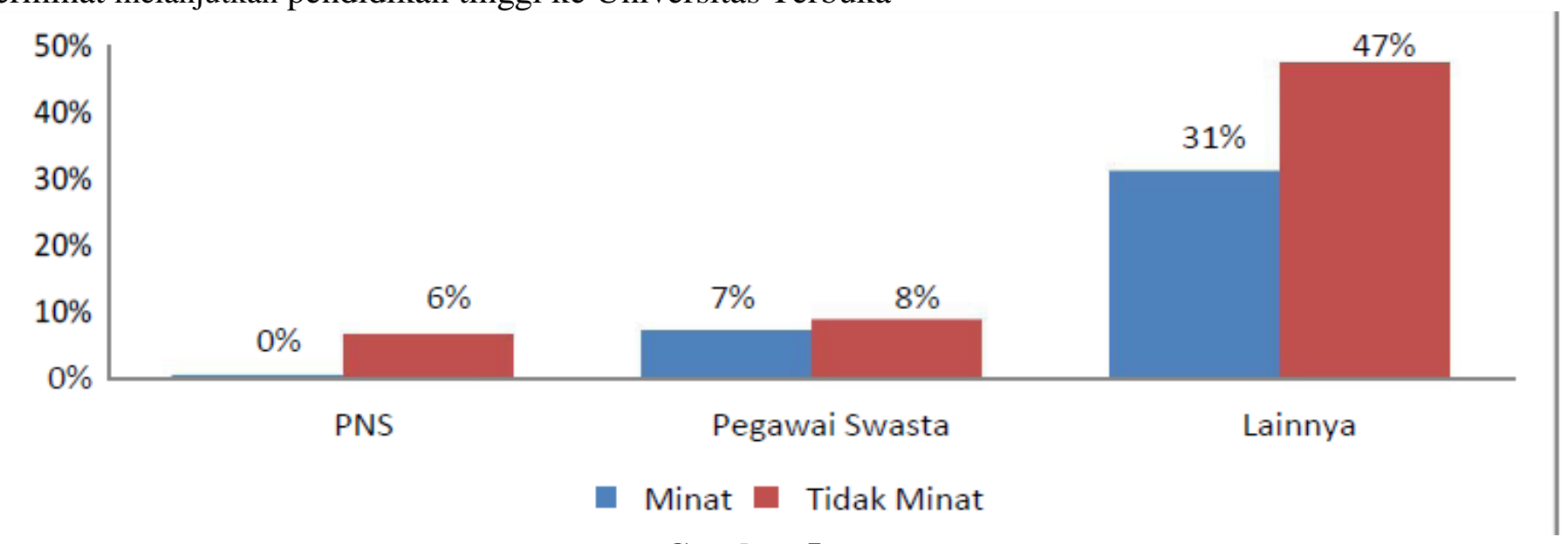

Gambar 5.

Karakteristik Minat Siswa SLTA sederajat Negeri/Swasta di Provinsi Jambi untuk Melanjutkan Pendidikan Tinggi ke Universitas Terbuka berdasarkan Pekerjaan Ayah

\section{Pekerjaan Ibu}

Hanya sebesar 38 persen siswa SLTA sederajat Negeri/Swasta di Provinsi Jambi yang berminat untuk melanjutkan pendidikan tinggi ke Universitas Terbuka berdasarkan karakteristik Pekerjaan Ibu. Sementara sebesar 62 persen yang tidak berminat. 


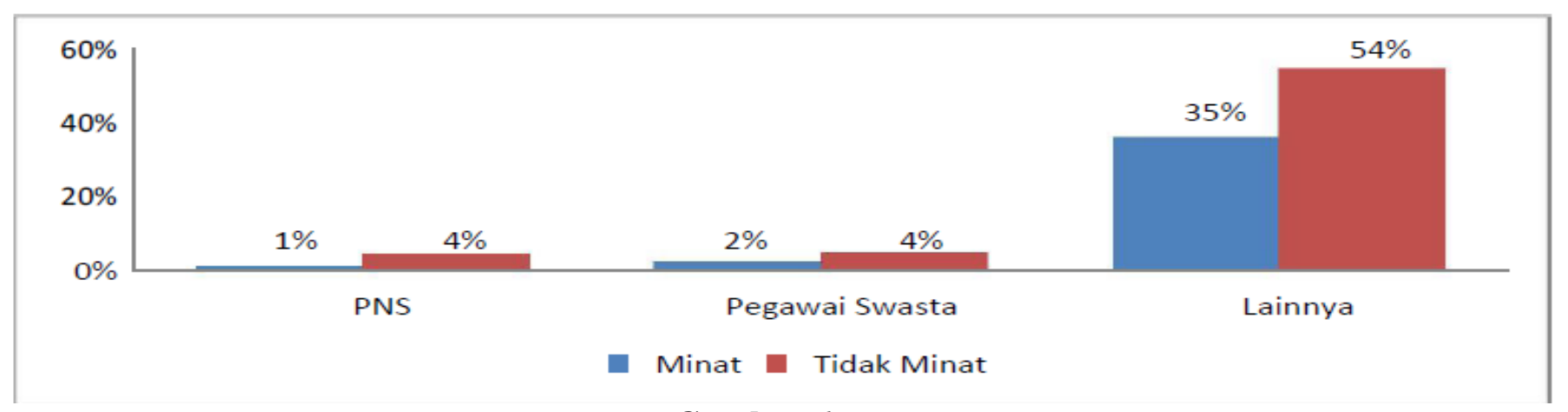

Gambar 6.

Karakteristik Minat Siswa SLTA sederajat Negeri/Swasta di Provinsi Jambi untuk Melanjutkan Pendidikan Tinggi ke Universitas Terbuka berdasarkan Pekerjaan Ibu

\section{Rata-rata Pendapatan Orang Tua}

Persentase karakteristik rata-rata pendapatan orang tua sebesar Rp 500.000-Rp 2.000.000 adalah persentase pendapatan yang paling besar mengenai berminatnya siswa SLTA Negeri/Swasta di Provinsi Jambi untuk melanjutkan pendidikan tinggi ke Universitas Terbuka, yaitu sebesar 23 persen. Pendapatan orang tua tersebut termasuk ke dalam ekonomi menengah dan Universitas Terbuka membantu bagi kalangan ekonomi lemah untuk dapat mengakses pendidikan tinggi (Gambar 7).

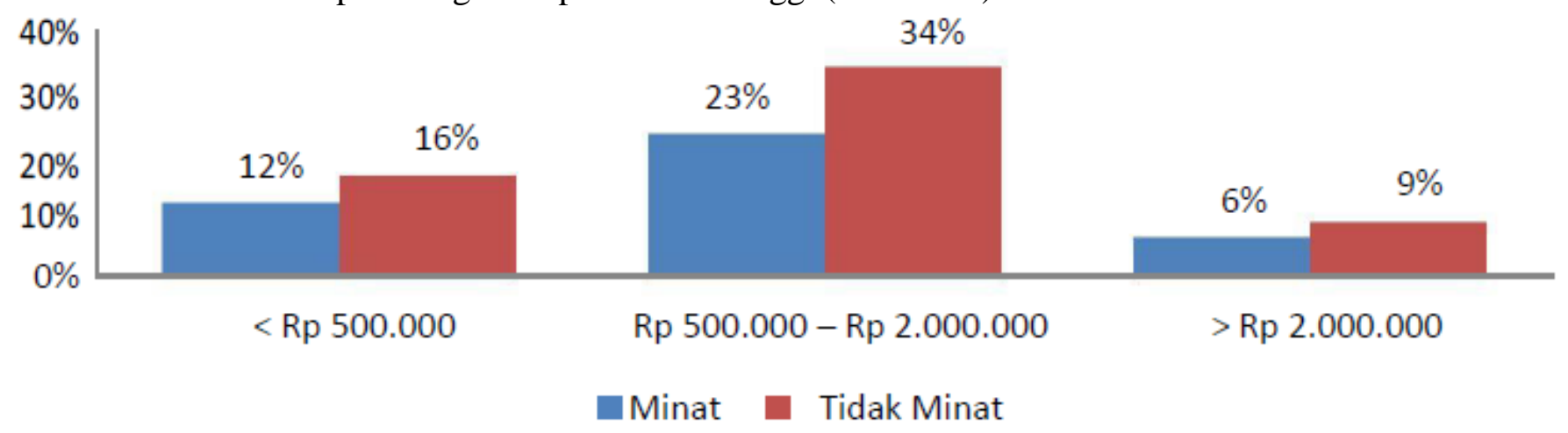

Gambar 7.

Karakteristik Minat Siswa SLTA sederajat Negeri/Swasta di Provinsi Jambi untuk Melanjutkan Pendidikan Tinggi ke Universitas Terbuka berdasarkan Rata-rata Pendapatan Orang Tua

\section{Pelajaran yang Disukai}

Gambar 8 menunjukkan bahwa sebesar 22 persen siswa SLTA sederajat Negeri/Swasta di Provinsi Jambi yang berminat untuk melanjutkan pendidikan tinggi ke Universitas Terbuka adalah yang menyukai atau duduk di kleas ilmu-ilmu sosial.

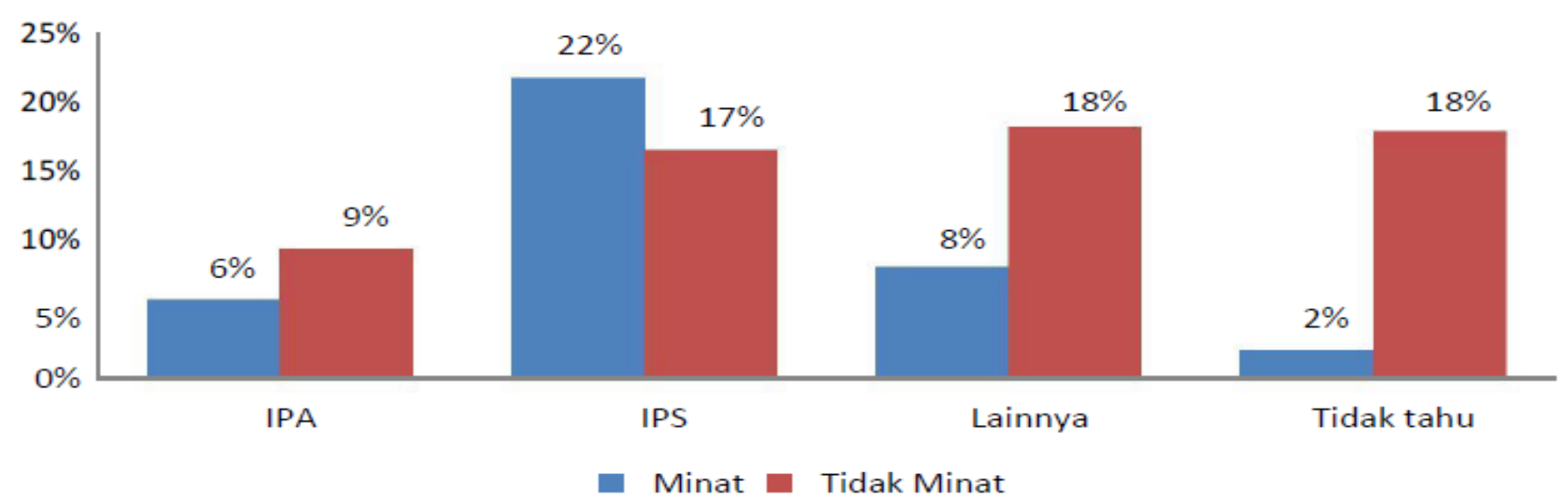




\section{Gambar 8.}

Karakteristik Minat Siswa SLTA sederajat Negeri/Swasta di Provinsi Jambi untuk Melanjutkan Pendidikan Tinggi ke Universitas Terbuka berdasarkan Pelajaran yang Disukai

\section{Perguruan Tinggi Saudara Berkuliah}

Keluarga siswa yang pernah kuliah di Universitas Terbuka memberi peluang minat siswa untuk melanjutkan pendidikan tinggi ke Universitas Terbuka, yaitu sebesar 5 persen. Sementara yang tidak memiliki keluarga yang berkuliah dimanapun memiliki peluang minat untuk melanjutkan pendidikan tinggi ke Universitas Terbuka, yaitu sebesar 27 persen (Gambar 9).

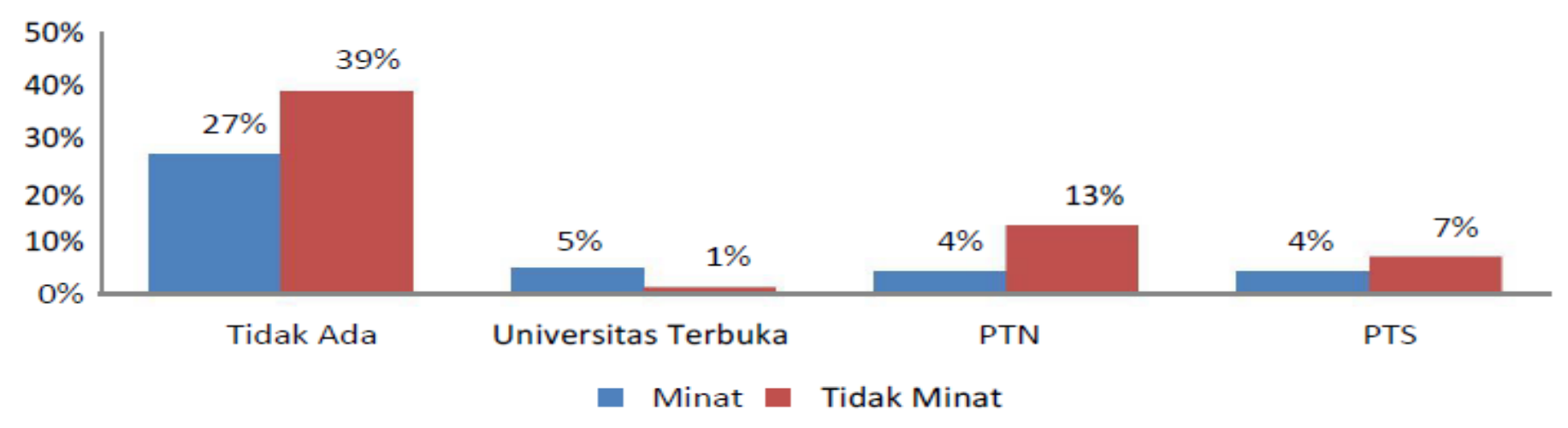

Gambar 9.

Karakteristik Minat Siswa SLTA sederajat Negeri/Swasta di Provinsi Jambi untuk Melanjutkan Pendidikan Tinggi ke Universitas Terbuka berdasarkan Perguruan Tinggi Saudara Berkuliah

\section{Faktor Pendorong Memilih Perguruan Tinggi}

Gambar 10 menunjukkan bahwa minat siswa SLTA Negeri/Swasta di Provinsi Jambi untuk melanjutkan pendidikan tinggi ke Universitas Terbuka yang berasal dari dalam diri sendiri menunjukkan persentase terbesar, yaitu 35 persen. Walaupun persentase terbesar juga berasal dari keinginan dalam diri sendiri untuk tidak berminat melanjutkan pendidikan tinggi ke Universitas Terbuka.

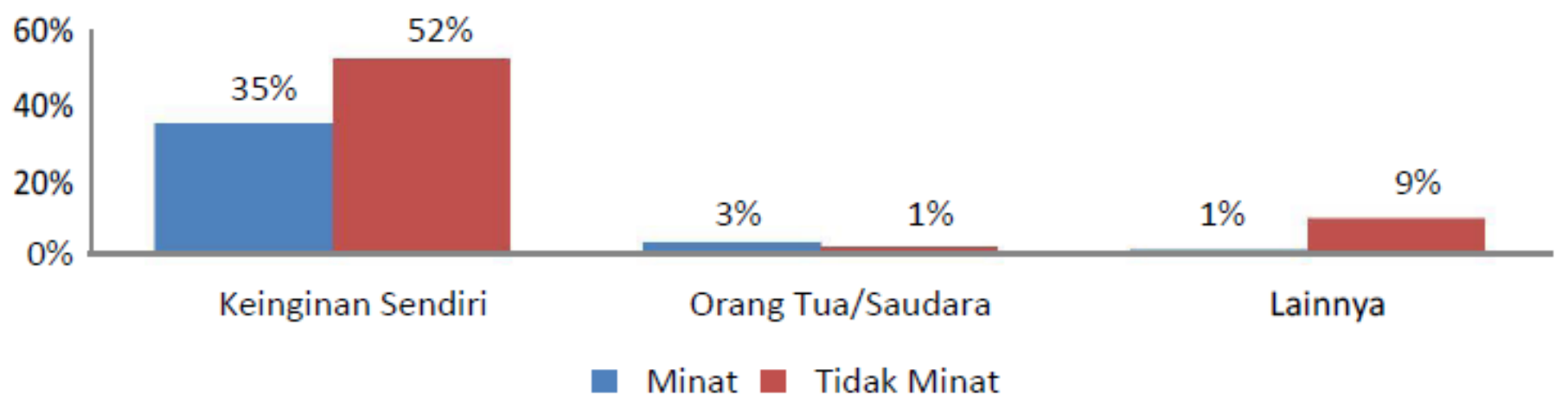

Gambar 10.

Karakteristik Minat Siswa SLTA sederajat Negeri/Swasta di Provinsi Jambi untuk Melanjutkan Pendidikan Tinggi ke Universitas Terbuka berdasarkan Faktor Pendorong Memilih Perguruan Tinggi

\section{Nilai Raport}

Nilai raport yang rendah menunjukan minat dan tidak berminat terbesar siswa SLTA Negeri/Swasta di Provinsi Jambi untuk melanjutkan pendidikan tinggi ke Universitas Terbuka, yaitu masing-masing sebesar 28 dan 41 persen. Ini menunjukkan bahwa siswa yang memiliki prestasi akademik yang tinggi masih lebih sedikit persentasenya untuk melanjutkan pendidikan tinggi ke Universitas Terbuka (Gambar 11). 


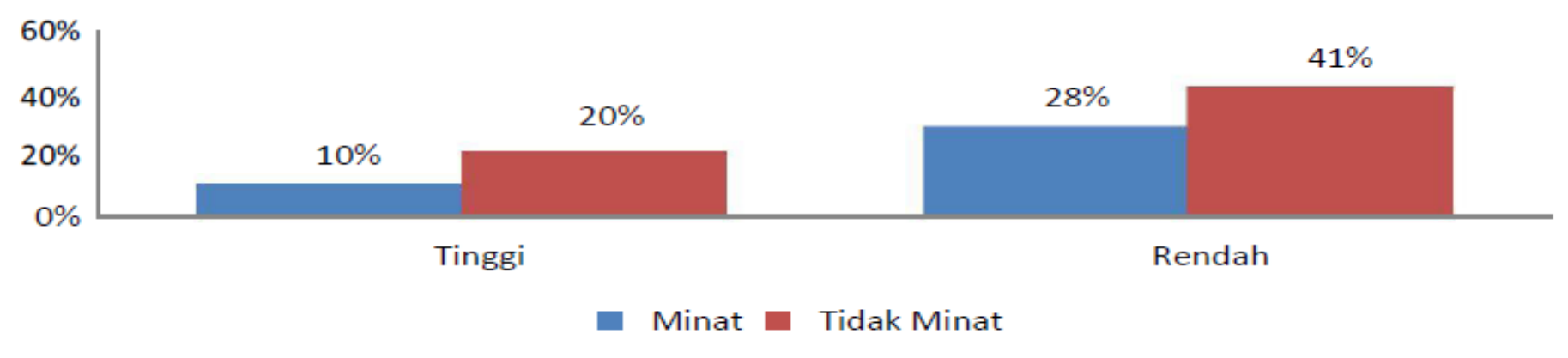

\section{Gambar 11.}

Karakteristik Minat Siswa SLTA sederajat Negeri/Swasta di Provinsi Jambi untuk Melanjutkan Pendidikan Tinggi ke Universitas Terbuka berdasarkan Nilai Raport

\section{Tempat Tinggal Siswa}

Sementara itu pada Gambar 12 menunjukkan bahwa siswa yang tinggal dengan orang tua masih menunjukkan minat terbesar untuk melanjutkan pendidikan tinggi ke Universitas Terbuka dibandingkan yang tinggal dengan saudara atau kost dan asrama.

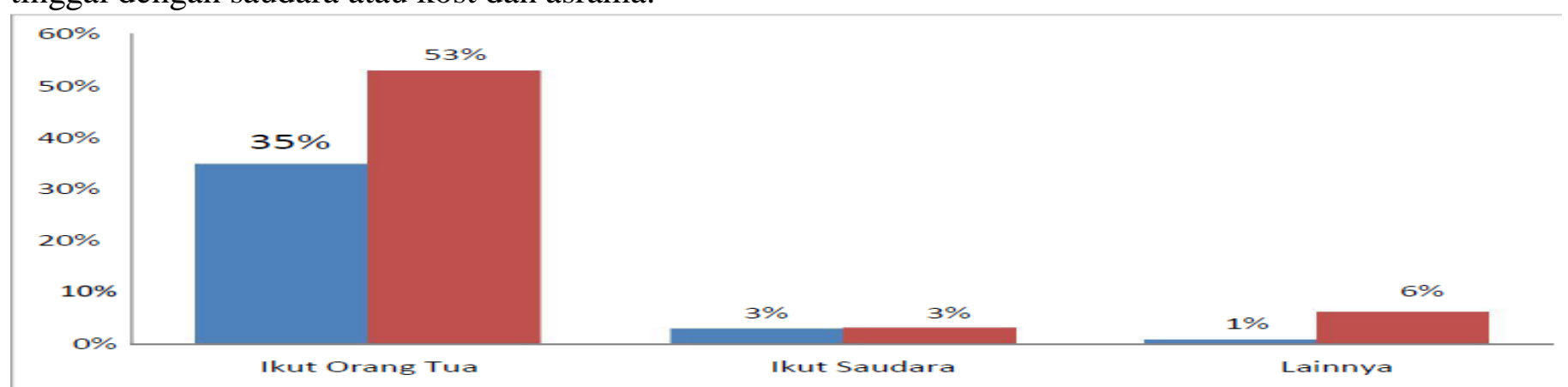

Gambar 12.

Karakteristik Minat Siswa SLTA sederajat Negeri/Swasta di Provinsi Jambi untuk Melanjutkan Pendidikan Tinggi ke Universitas Terbuka berdasarkan Tempat Tinggal Siswa

\section{Analisis Regresi Logistik}

Analisis regresi logistik dimulai dengan seleksi bivariat. Kemudian dipilih variabel independent yang memenuhi persyaratan untuk dipilih dan dilakukan analisis selanjutnya, yaitu analisis multivariate.

\section{Seleksi Bivariat}

Tahap pertama dalam melakukan analisis regresi logistik adalah seleksi bivariat, di mana di dalam analisis bivariat dilakukan uji signifikansi setiap variabel independent dengan variable dependent (tidak keseluruhan variabel independent). Bila hasil analisis variabel bivariat antara variabel dependent dengan variabel independent menghasilkan $\mathrm{P}<0,25$, maka variabel independent tersebut dimasukkan ke dalam tahap analisis multivariat. Pada Tabel 1 menunjukkan bahwa variabel status anak, pendidikan ibu, dan rata-rata pendapatan bukan kandidat atau tidak dimasukkan ke dalam tahap analisis multivariat.

Tabel 1.

Seleksi Bivariat

\begin{tabular}{|c|c|c|c|}
\hline No. & Variabel & P-Value & Keterangan \\
\hline 1. & Jenis kelamin & 0,010 & Kandidat \\
\hline 2. & Status anak & 0,457 & Bukan kandidat \\
\hline 3. & Pendidikan ayah & 0,046 & Kandidat \\
\hline 4. & Pendidikan ibu & 0,357 & Bukan kandidat \\
\hline 5. & Pekerjaan ayah & 0,000 & Kandidat \\
\hline 6. & Pekerjaan ibu & 0,057 & Kandidat \\
\hline 7. & Rata-rata pendapatan & 0,289 & Bukan kandidat \\
\hline 8. & Pelajaran yang disukai & 0,000 & Kandidat \\
\hline
\end{tabular}




$\begin{array}{rlrr}\text { 9. } & \text { Perguruan tinggi saudara berkuliah } & 0,000 & \text { Kandidat } \\ \text { 10. } & \text { Faktor pendorong memilih perguruan tinggi } & 0,000 & \text { Kandidat } \\ \text { 11. } & \text { Nilai raport } & 0,174 & \text { Kandidat } \\ 12 . & \text { Tempat tinggal siswa } & 0,005 & \text { Kandidat }\end{array}$

\section{Pemodelan Multivariat}

Bila hasil analisis variabel multivariate antara variabel dependent dengan semua kandidat variabel independent menghasilkan $\mathrm{P}>0,05$, maka variabel independent tersebut dikeluarkan untukmenuju ke tahap analisis multivariat selanjutnya.

Tabel 2.

Pemodelan Multivariat I

\begin{tabular}{llrrrrr}
\hline No. & \multicolumn{1}{c}{ Variabel } & B & P-Value & OR & \multicolumn{2}{c}{ 95\% CI } \\
& & & & & Lower & Upper \\
\hline 1. & Jenis kelamin & 0,779 & 0,002 & 2,179 & 1,318 & 3,602 \\
2. & Pendidikan ayah & $-0,222$ & 0,365 & 0,801 & 0,496 & 1,295 \\
3. & Pekerjaan ayah & 0,430 & 0,117 & 1,537 & 0,897 & 2,632 \\
4. & Pekerjaan ibu & 0,187 & 0,592 & 1,205 & 0,609 & 2,384 \\
5. & Pelajaran yang disukai & $-0,554$ & 0,000 & 0,575 & 0,430 & 0,769 \\
6. & Perguruan tinggi saudara berkuliah & $-0,061$ & 0,602 & 0,941 & 0,749 & 1,183 \\
7. & Faktor pendorong memilih perguruan tinggi & $-0,476$ & 0,091 & 0,621 & 0.358 & 1,079 \\
8. & Nilai raport & 0,296 & 0,295 & 1,344 & 0,773 & 2,338 \\
9. & Tempat tinggal siswa & $-0,667$ & 0,015 & 0,513 & 0,299 & 0,879 \\
\hline
\end{tabular}

Pada pemodelan multivariat I menuju pemodelan Multivariat II, variabel independent yang dikeluarkan adalah pendidikan ayah karena memiliki P>0,05, yaitu 0,365 (Tabel II).

Tabel 3.

Pemodelan Multivariat II

\begin{tabular}{llrrrrrr}
\hline No. & Variabel & B & P- Value & OR & \multicolumn{2}{c}{ 95\% CI } & Perubahan \\
& & & & & Lower & Upper & \\
\hline 1. & Jenis kelamin & 0,749 & 0,003 & 2,114 & 1,286 & 3,475 & $2,98 \%$ \\
2. & Pekerjaan ayah & 0,516 & 0,045 & 1,676 & 1,012 & 2,774 & $9,04 \%$ \\
3. & Pekerjaan ibu & 0,244 & 0,475 & 1,276 & 0,653 & 2,493 & $5,89 \%$ \\
4. & Pelajaran yang disukai & $-0,553$ & 0,000 & 0,575 & 0,430 & 0,769 & $0 \%$ \\
5. & Perguruan tinggi saudara berkuliah & $-0,080$ & 0,486 & 0,923 & 0,737 & 1,156 & $1,91 \%$ \\
6. & Faktor pendorong memilih perguruan tinggi & $-0,485$ & 0,085 & 0,616 & 0,354 & 1,069 & $0,81 \%$ \\
7. & Nilai raport & 0,307 & 0,277 & 1,359 & 0,782 & 2,362 & $1,12 \%$ \\
8. & Tempat tinggal siswa & $-0,664$ & 0,015 & 0,515 & 0,301 & 0,881 & $0,39 \%$ \\
\hline
\end{tabular}

Adapun pada pemodelan multivariate II menuju pemodelan Multivariat III, variabel independent yang dikeluarkan adalah pekerjaan ibu karena memiliki P>0,05, yaitu 0,475 (Tabel III).

Tabel 4.

Pemodelan Multivariat III

\begin{tabular}{|c|c|c|c|c|c|c|c|}
\hline \multirow[t]{2}{*}{ No. } & \multirow[t]{2}{*}{ Variabel } & \multirow[t]{2}{*}{ B } & \multirow[t]{2}{*}{ P-Value } & \multirow[t]{2}{*}{ OR } & \multicolumn{2}{|c|}{ 95\% CI } & \multirow[t]{2}{*}{ Perubahan } \\
\hline & & & & & Lower & Upper & \\
\hline 1. & Jenis kelamin & 0,758 & 0,003 & 2,134 & 1,300 & 3,503 & $0,95 \%$ \\
\hline 2. & Pekerjaan ayah & 0,590 & 0,013 & 1,805 & 1,135 & 2,870 & $7,70 \%$ \\
\hline 3. & Pelajaran yang disukai & $-0,562$ & 0,000 & 0,570 & 0,427 & 0,762 & $0,87 \%$ \\
\hline 4. & Perguruan tinggi saudara berkuliah & $-0,081$ & 0,478 & 0,922 & 0,736 & 1,154 & $0,11 \%$ \\
\hline 5 . & Faktor pendorong memilih perguruan tinggi & $-0,486$ & 0,085 & 0,615 & 0,354 & 1,069 & $0,16 \%$ \\
\hline 6. & Nilai raport & 0,324 & 0,248 & 1,383 & 0,798 & 2,397 & $1,77 \%$ \\
\hline 7. & Tempat tinggal siswa & $-0,660$ & 0,016 & 0,517 & 0,302 & 0.884 & $0,39 \%$ \\
\hline
\end{tabular}


Pemodelan multivariate III menuju pemodelan Multivariat IV, variabel independent yang dikeluarkan adalah perguruan tinggi saudara berkuliah karena memiliki $\mathrm{P}>0,05$, yaitu 0,478 (Tabel 4).

Tabel 5.

Pemodelan Multivariat IV

\begin{tabular}{llrrrrrr}
\hline No. & Variabel & B & P- Value & OR & \multicolumn{2}{c}{ 95\% CI } & Perubahan \\
& & & & & & Lower & Upper \\
& Jenis kelamin & 0,758 & 0,003 & 2,135 & 1,301 & 3,504 & $0,05 \%$ \\
2. & Pekerjaan ayah & 0,613 & 0,009 & 1,846 & 1,166 & 2,921 & $2,27 \%$ \\
3. & Pelajaran yang disukai & $-0,567$ & 0,000 & 0,567 & 0,424 & 0,758 & $0,53 \%$ \\
4. & Faktor pendorong memilih perguruan tinggi & $-0,463$ & 0,099 & 0,630 & 0,363 & 1,091 & $2,44 \%$ \\
5. & Nilai raport & 0,337 & 0,229 & 1,400 & 0,809 & 2,424 & $1,23 \%$ \\
6. & Tempat tinggal siswa & $-0,651$ & 0,017 & 0,521 & 0,305 & 0,890 & $0,77 \%$ \\
\hline
\end{tabular}

Pemodelan multivariate IV menuju pemodelan Multivariat $\mathrm{V}$, variabel independent yang dikeluarkan adalah faktor pendorong memilih perguruan tinggi karena memiliki P>0,05, yaitu 0,099 (Tabel 5).

Tabel 6.

Pemodelan Multivariat V

\begin{tabular}{rlrrrrrr}
\hline No. & Variabel & B & P-Value & OR & \multicolumn{2}{c}{ 95\% CI } & Perubahan \\
& & & & & Lower & Upper & \\
\hline 1. & Jenis kelamin & 0,750 & 0,003 & 2,117 & 1,293 & 3,466 & $0,84 \%$ \\
2. & Pekerjaan ayah & 0,572 & 0,015 & 1,772 & 1,120 & 2,805 & $4,01 \%$ \\
3. & Pelajaran yang disukai & $-0,679$ & 0,000 & 0,507 & 0,390 & 0,660 & $10,58 \%$ \\
4. & Nilai raport & 0,373 & 0,181 & 1,452 & 0,840 & 2.510 & $3,71 \%$ \\
5. & Tempat tinggal siswa & $-0,604$ & 0,026 & 0,547 & 0,321 & 0,931 & $4,99 \%$ \\
\hline
\end{tabular}

Satu lagi persyaratan analisis Regresi Logistik adalah persyaratan perubahan OR. Jika perubahan OR lebih dari 10 persen, maka variabel independent yang sebelumnya telah dihilangkan, dimunculkan kembali dan mengeliminasi variabel independent lainnya yang memiliki nilai $\mathrm{P}>0,05$. Oleh sebab itu, karena variabel pelajaran yang disukai memiliki nilai perubahan $\mathrm{OR}>10 \%$, maka variabel faktor pendorong memilih perguruan tinggi dimasukkan kembali dan mengeliminasi variabel nilai raportyang memiliki nilai P>0,05(Tabel 7).

Tabel 7.

Pemodelan Multivariat VI

\begin{tabular}{|c|c|c|c|c|c|c|c|}
\hline \multirow[t]{2}{*}{ No. } & \multirow{2}{*}{ Variabel } & \multirow[t]{2}{*}{ B } & \multirow[t]{2}{*}{ P-Value } & \multirow[t]{2}{*}{ OR } & \multicolumn{2}{|c|}{ 95\% CI } & \multirow{2}{*}{ Perubahan } \\
\hline & & & & & Lower & Upper & \\
\hline 1. & Jenis kelamin & 0,775 & 0,002 & 2,171 & 1,325 & 3,555 & $1,69 \%$ \\
\hline 2. & Pekerjaan ayah & 0,667 & 0,004 & 1,948 & 1,241 & 3,058 & $5,53 \%$ \\
\hline 3. & Pelajaran yang disukai & $-0,543$ & 0,000 & 0,581 & 0,436 & 0,773 & $2,47 \%$ \\
\hline 4. & Faktor pendorong memilih perguruan tinggi & $-0,486$ & 0,082 & 0,615 & 0,356 & 1,064 & $2,38 \%$ \\
\hline 5. & Tempat tinggal siswa & $-0,652$ & 0,017 & 0,521 & 0,305 & 0,890 & $0 \%$ \\
\hline
\end{tabular}

Pemodelan multivariate VI menuju pemodelan Multivariat VII, variabel independent yang dikeluarkan adalah faktor pendorong memilih perguruan tinggi karena memiliki P>0,05, yaitu 0,082 (Tabel 8). 
Tabel 8.

Pemodelan Multivariat VII

\begin{tabular}{llrrrrrr}
\hline No. & Variabel & B & P-Value & OR & \multicolumn{2}{c}{$\mathbf{9 5 \%}$ CI } & Perubahan \\
& & & & & Lower & Upper & \\
\hline 1. & Jenis kelamin & 0,769 & 0,002 & 2,158 & 1,321 & 3,525 & $0,60 \%$ \\
2. & Pekerjaan ayah & 0,629 & 0,006 & 1,875 & 1,193 & 2,948 & $3,75 \%$ \\
3. & Pelajaran yang disukai & $-0,659$ & 0,000 & 0,517 & 0,399 & 0,671 & $11,02 \%$ \\
4. & Tempat tinggal siswa & $-0,601$ & 0,779 & 0,549 & 0,322 & 0,934 & $5,37 \%$ \\
\hline
\end{tabular}

Pemodelan multivariate VII menunjukkan bahwa variabel pelajaran yang disukai memiliki nilai perubahan OR lebih dari $10 \%$, yaitu $11,02 \%$. Karena variabel pelajaran yang disukai memiliki perubahan OR $>10 \%$, maka variabel faktor pendorong memilih perguruan tinggi dimasukkan kembali dan tidak ada yang dieliminasi dikarenakan semua variabel independent memiliki nilai $\mathrm{P}<0,05$ (kecuali variabel faktor pendorong memilih perguruan tinggi).Hal ini seperti yang terlihat pada Tabel 9.

Tabel 9.

Pemodelan Multivariat Akhir

\begin{tabular}{llrrrrrr}
\hline No. & Variabel & B & P-Value & OR & \multicolumn{2}{c}{$\mathbf{9 5 \%}$ CI } & Perubahan \\
& & & & & Lower & Upper & \\
\hline 1. & Jenis kelamin & 0,775 & 0,002 & 2,171 & 1,325 & 3,555 & $1,69 \%$ \\
2. & Pekerjaan ayah & 0,667 & 0,004 & 1,948 & 1,241 & 3,058 & $5,53 \%$ \\
3. & Pelajaran yang disukai & $-0,543$ & 0,000 & 0,581 & 0,436 & 0,773 & $2,47 \%$ \\
4. & Faktor pendorong memilih perguruan tinggi & $-0,486$ & 0,082 & 0,615 & 0,356 & 1,064 & $2,38 \%$ \\
5. & Tempat tinggal siswa & $-0,652$ & 0,017 & 0,521 & 0,305 & 0,890 & $0 \%$ \\
6. & Konstanta & 0,038 & 0,959 & 1,039 & & & \\
\hline
\end{tabular}

Tabel 9 menunjukkan bahwa variabel-variabel yang berpengaruh signifikan terhadap minat siswa dalam melanjutkan pendidikan tinggi ke Universitas Terbuka adalah variabel jenis kelamin, pekerjaan ayah, pelajaran yang disukai, dan tempat tinggal siswa. Hal ini dikarenakan nilai $\mathrm{P}<$ alpha (5\%). Di antara variabel independent yang berpengaruh signifikan tersebut, variabel yang paling dominan mempengaruhi minat siswa dalam melanjutkan pendidikan tinggi ke Universitas Terbuka adalah jenis kelamin. Hal ini dikarenakan nilai Odds Ratio (OR) nya paling tinggi di antara variabel independent lainnya, yaitu 2,171. Sementara itu, variabel faktor pendorong memilih perguruan tinggi bukanlah variabel yang signifikan mempengaruhi minat siswa dalam melanjutkan pendidikan tinggi ke Universitas Terbuka karena nilai P>alpha (5\%).

\section{Evaluasi Kebaikan Model}

Dari uji parameter dan odds rasio maka diperoleh model yang dapat digunakan dalam menduga faktorfaktor yang mempengaruhi minat siswa dalam melanjutkan pendidikan tinggi ke Universitas Terbuka, dimana model peluang regresi logistik dengan transformasi logit adalah sebagai berikut :

$$
\mathrm{g}^{\wedge}(x)=0,038+0,775 \mathrm{X} 1+0,667 \mathrm{X} 5+-0,543 \mathrm{X} 8+-0,486 \mathrm{X} 10+-0,652 \mathrm{X} 12
$$

\section{SIMPULAN}

Berdasarkan hasil penelitian Analisis Kepemilikan Soft Skill mahasiswa Program Studi Pendidikan Ekonomi FKIP Universitas Jambi dapat disimpulkan bahwa 1) atribut soft skills yang sudah dimiliki mahasiswa secara keseluruhan sangat baik dengan Frekuensi Relatif 63,91\%,2) kemampuan soft skills mahasiswa secara per angkatan , 2015, 2016 dan 2017 sangat baik dengan frekuensi absolut 36 dan frekuensi relative 69,23\% dan Kemampuan Soft Skills Mahasiswa perangkatan mengalami kenaikan dari tahun 2015 sampai dengan 2017,3) kemampuan berdasarkan gender Soft Skills mahasiswa yang berjenis kelamin perempuan lebih tinggi dari pada laki-lakin dengan kemampuan rata-rata sangat baik dengan hasil count 25 untuk laki-laki dan perempuan count 122, dan 4) Soft Skills mahasiswa berdasarkan asal dari kampung dan kota, hasil analisis diperoleh koefesien $\mathrm{F}$ hitung sebesar 0,218 dengan tingkat penolakan 
64,10\% dengan demikian tidak ada bedanya kemampuan rata-rata soft skills mahasiswa mahasiswa yang berasal dari kota dan dari desa. Dengan itu dapat dilihat bahawa mahasiswa dari desa lebih tinggi soft skillsnya dari pada mahasiswa dari kota.

\section{DAFTAR PUSTAKA}

Abbas, R., Abdul Kadir, F. A., \& Ghani Azmie, I. A. 2013. Integrating Soft Skills Assessment Through Soft Skills Workshop Program For Engineering Students At University Of Pahang: An Analysis. International Journal of Research In Social Science, 2(1), 33-46.

Anthony, S. ,2014. Integrating Soft Skills in the Curriculum without Sacrificing Content. Journal for Academic Excellence, 2(4), 1-57.

Azwar Saifuddin. 2014. Reliabilitas dan Validitas. Yogyakarta:Pustaka Pelajar

Cimatti, B. 2016. Definition, Development, Assesment of Soft Skill and Their Role for The Quality of Organizations and Enterprises. International Journal for Quality Research, 10(1), 97-130.

Djaali \& Pudji, M. 2012, Pengukuran dalam Bidang Pendidikan. Jakarta : Grasindo.

Haryati, Sri, 2012, Research and Development (R\&D) Sebagai Salah Satu Model Penelitian Dalam Bidang

Pendidikan, Vol 35 No.1 Tanggal 15 September 2012:11-26

Herlambang, Susatyo, 2012, Personality development, Yogyakarta : Gosyen Publishing.

Ibrahim, Amin, 2015, Teori dan Konsep Pelayanan Publik Serta Implementasinya, Bandung : Mandar Maju.

Illah, Sailah, 2013, Pengembangan Soft Skill di Perguruan Tinggi: Eidi Revisi, Jakarta ; Direktorat Jendral Perguruan Tinggi.

Ilias, A., Abd Razak, M. Z., Yeop Yunus, N. K., \& Abd Razak, S. F. 2012. How Accounting Students Perceived Towards Teamwork Skills. Journal of Education and Vocational Research, 3(12), 387-398.

Lawrence A.Pervin, 2015, Psikologi Kepribadian, Jakarta : Kencana.

Muqowim, 2012, Pengembangan Soft Skill Guru, Yogyakarta : Pedagogia.

Majid, S., Liming, Z., Tong, S., \& Raihana, S. 2012. Importance of Soft Skills for Education and Career Success. International Journal for Cross-Disciplinary Subjects in Education (IJCDSE), 2(2), 10361042.

Myers, T., Blackman, A., Andersen, T., Hay, R., \& Lee, I. 2014. Cultivating ICT Student's International Soft Skills In Online Learning Environments Using Traditional Active Learning Techniques. Journal of Learning Design, 7(3), 38-53.

Naga, D. Santun. 2013. Teori Sekor Pada Pengukuran Mental. Jakarta: Nagarani Citrayasa

Nealy, C. 2015. Integrating Soft Skills Through Active Learning In The Management Classroom. Journal of College Teaching \& Learning, 2(4), 1-6.

Nugrohadi, Edwi dkk, 2013, Menjadi Pribadi Religius dan Humanis, Yogyakarta : Graha Ilmu.

Paolini, A. C. 2015. School Counselor's Role in Facilitating the Development of Students' Soft Skills: Intrapersonal and Interpersonal Attributes to Promote Career Readiness. Global Journal of HumanSocial Science, 15(10), 1-10.

Ramlall, S., \& Ramlall, D. 2014. The Value of Soft-Skills in the Accounting Profession: Perspectives of Current Accounting Students. Advances in Research, 2(11), 645-654.

Richer, Rita C, Klein, 2012, Design and Developmen Research : An Introduction, Fifth Edition, New York : Longman.

Robles, M. 2012. Executive Perceptions of the Top 10 Soft Skills Needed in Today's Workplace. Business Communication Quarterly, 75(4), 453-465.

Sudaryono dkk, 2013, Pengembangan Instrumen Penelitian Pendidikan, Yogyakarta : Graha Ilmu.

Suryabrata, Sumadi. 2014. Metodologi Penelitian. Jakarta: Rajawali Pers.

Syaodih, Nana Sukmadinata,2012. Metode Penelitian Pendidikan, Bandung : PT Remaja Rosdakarya

Taylor, E. 2016. Investigating the Perception of Stakeholders on Soft Skills Development of Students: Evidence from South Africa. Interdisciplinary Journal of e-Skills and Lifelong Learning, 12(1), 1-18.

Wahyu Widhiarso, 2012. Evaluasi Soft Skills Dalam Konteks Pembelajaran. BENEFIT Jurnal Manajemen dan Bisnis Volume 17, Nomor 3, Desember 2012, hlm 79-90.

Wisnuwardhani dan Mashoedi, 2012, Hubungan Interpersonal, Jakarta : Salemba Humanika. 